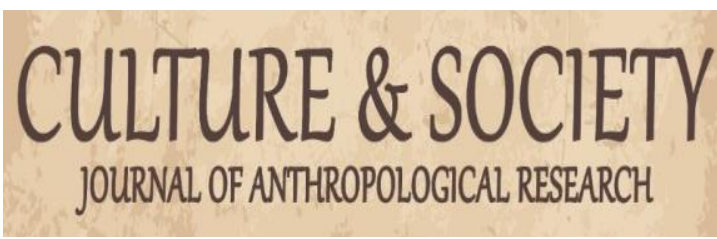

Culture \& Society: Journal of Anthropological Research

VOL. 2 NO. 1 SEPTEMBER 2020

http://culture.ppj.unp.ac.id

Email: culture@ppj.unp.ac.id

ISSN: 2686-343X (E-ISSN) 2686-3421 (P-ISSN)

DOI: https://doi.org/10.24036/csjar.v2i1.50

\title{
Minat Remaja Perempuan Belajar Bertenun Pada Masyarakat Desa Silungkang Duo Kota Sawahlunto
}

\author{
Resti Yulia Putri ${ }^{1}$, Erianjoni Erianjoni ${ }^{2}$ \\ ${ }^{1,2}$ Universitas Negeri Padang \\ Email: restiyulia709@gmail.com, erianjoni@fis.unp.ac.id
}

\begin{abstract}
Abstrak
Penelitian ini dilatarbelakangi dengan kurangnya minat remaja perempuan belajar bertenun pada masyarakat Desa Silungkang Duo Kecamatan Silungkang Kota Sawahlunto. Penelitian ini bertujuan untuk mengetahui faktor kurangnya minat remaja perempuan belajar bertenun pada masyarakat Desa Silungkang Duo Kecamatan Silungkang Kota Sawahlunto. Metode yang digunakan pendekatan kualitatif, tipe penelitian studi kasus. Pemilihan informan dilakukan secara purposive sampling. Pengumpulan data secara observasi partisipasi pasif, wawancara mendalam, dan dokumentasi. Data dianalisis dengan teknik analisis interaktif Miles dan Huberman dengan cara reduksi data, penyajian data dan penarikan kesimpulan. Hasil penelitian menunjukan ada beberapa faktor penyebab kurangnya minat remaja perempuan belajar bertenun diantaranya: Bertenun sebagai suatu pekerjaan yang membosankan, Pengaruh Pendidikan, Pilihan Pekerjaan yang Sudah Semakin Banyak, serta Kurangnya Motivasi dan Daya Tarik yang diberikan Kepada Remaja Perempuan Untuk Belajar Bertenun. Berdasarkan penjelasan tersebut peneliti menemukan bahwasanya minat remaja perempuan belajar bertenun mengalami penurunan, hal ini menandakan rendahnya $n A c h$ yang dimiliki remaja perempuan untuk belajar bertenun. Oleh karena itu dibutuhkan peran beberapa pihak untuk meningkatkan need for achievement remaja perempuan untuk belajar bertenun.
\end{abstract}

Kata kunci: Bertenun, Minat, Remaja Perempuan

\section{Abstract}

This research is motivated by the lack of interest in adolescent girls learning to weave in the community of Silungkang Duo Village, Silungkang District, Sawahlunto City. This study aims to determine the factor of lack of interest in adolescent girls learning to weave in Silungkang Duo Village, Silungkang District, Sawahlunto City. The metode used is a qualitative approach, type of case study research. The selection of informants was carried out by purposive sampling. Data collection was done through passive participation observation, in-depth interviews, and documentation. Data were analyzed using Miles and Huberman's interactive analysis techniques by data reduction, data presentation and conclusion drawing. The results showed that there were several factors causing the lack of interest in adolescent girls learning to weave including: weaving as a tedious job, Effects of Education, Increasingly More Job Choices, and Lack of Motivation and Attractiveness Given to Adolescent Girls for Learning to Work. Based on the explanation, the researchers found that the interest of adolescent girls learning to weave has descreased, this indicates the low number of young women posessed to learn to weave. Therefore we need the role of several parties, to increase the need for achievement of young women to learn to weave.

Keywords: Weave, Interests, Adolescent Girls

\begin{tabular}{|l|l|l} 
Received: July 30, 2020 & Revised: August 13, 2020 & Published: August 14, 2020
\end{tabular}

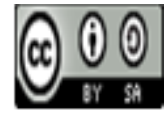

Culture \& Society: Journal of Anthropological Research Vol. 2, No. 1, Th. 2020 


\section{Pendahuluan}

Seni tradisional adalah bagian dari budaya daerah tertentu yang telah berkembang dalam sejarah kehidupan manusia, ia lahir dalam masyarakat, karena diperlukan dalam berbagai bentuk kebutuhan praktis masyarakat. Dengan demikian, keberadaannya tidak hanya bentuk pernyataan seni, tetapi juga merupakan manifestasi kehidupan masyarakat pendukungnya, atau ungkapan kreativitas dari kebudayaan itu sendiri.

Indonesia adalah negara yang terdiri dari beberapa wilayah dan memiliki beragam suku bangsa dan budaya di tiap daerah. Setiap daerah memiliki ciri khasnya masing-masing, dimana biasanya hasil budaya ini merupakan paduan dari daerah lain. Akan tetapi keragaman inilah yang membuat Indonesia kaya akan seni budayanya. Keragaman ini tergambar dalam banyaknya hasil budaya yang dihasilkan, seperti seni musik, seni pahat, seni tari, seni lukis, hingga seni tekstil. Seni tekstil di Indonesia beragam sesuai daerahnya masing-masing, salah satunya yaitu kerajinan songket (Sumiati, 2019). Kain songket merupakan warisan dari masa ke masa. Ditinjau dari segi filosofinya kain songket memiliki ragam hias yang mencerminkan berbagai cara hidup, adat istiadat, serta seni budaya para penenun dalam masyarakat dan alam lingkungannya. Sumatera Barat merupakan salah satu daerah penghasil tenunan yang memiliki ciri khas tersendiri disetiap daerahnya, seperti songket Pandaisikek, songket Silungkang, tenun Balapak Tanjung Sungayang, dan songket Kubang. Salah satu daerah yang menjadi objek penelitian adalah Silungkang (Aminah, Hos, \& Sarpin, 2020).

Seni kerajinan tenun songket di tengah-tengah masyarakat Silungkang, pada awalnya merupakan kegiatan sampingan. Tenun adalah salah satu tradisi yang diturunkan secara turuntemurun yang ada di Silungkang, tenun juga merupakan pelengkap pakaian tradisional dalam berbagai acara adat di Silungkang yang merupakan suatu simbol kebanggaan dalam masyarakat Silungkang (Maulia, 2015). Seiring dengan pertumbuhan penduduk dan keadaan geografis yang tidak memungkinkan untuk masyarakat memenuhi kebutuhan hidup di sektor lain, maka usaha pertenunan merupakan salah satu potensi yang dapat diandalkan dan dikembangkan seperti seni kerajinan songket ini. Sebagai salah satu bentuk pilihan usaha, maka bentuk produk seni kerajinan tenun songket sangat bervariasi, terutama untuk benda-benda yang mempunyai nilai kegunaan, seperti perangkat ritual adat, benda-benda dekorasi interior, yang digunakan sebagai busana, untuk berbagai keperluan. Dalam penciptaan produk yang mempunyai nilai fungsional, maka faktor kegunaan dan faktor estetis suatu produk menjadi prioritas utama sebagai daya tarik. Sebab suatu karya yang memiliki nilai fungsional yang tepat dan kualitas estetik yang memadai akan membangkitkan minat serta selera pemakai.

Keterampilan pengrajin tenun dalam membuat produk seni kerajinan merupakan warisan dari nenek moyangnya yang dilakukan secara turun-temurun. Usaha pertenunan di Silungkang lebih bersifat kekeluargaan, hanya melibatkan anggota keluarga. Pengrajin bukan hanya orang dewasa saja, melainkan anak-anak dan remaja sudah menekuni bidang ini. Sepulang dari sekolah mereka tidak bermain melainkan membuat tenun yang hasilnya dapat membantu perekenomian keluarga. Pengrajin tenun yang lebih didominasi oleh para kaum bundo kanduang itu sangat memiliki talenta seni dan keindahan yang dalam. Para ibu-ibu tidak segan mengajarkan ilmunya kepada anak cucu dan kaum kerabatnya serta siapa saja yang berminat diperbolehkan oleh masyarakat Silungkang, masyarakat Silungkang tidak menutup diri bagi orang luar, karena menurut mereka itu merupakan kredit poin bagi perkembangan produksi tenunnya di luar dari daerah Silungkang. Pengrajin tenun lebih banyak ditekuni oleh perempuan karena bertenun memerlukan ketelitian, keuletan, dan ketekunan yang tinggi dalam mengerjakannya. Sehingga perempuan lebih cocok melakukan pekerjaan itu, dibandingkan laki-laki (Aminah et al., 2020).

Pulang sekolah remaja perempuan Silungkang tidak asing dengan tenunnya, apalagi bagi mereka yang tidak melanjutkan sekolah semuanya ikut berbaur dengan hiruk-pikuknya sentak nada pertenunan. Yang lebih menarik lagi pekerjaan itu memberikan hasil yang dapat dinikmati 
terutama anak-anak gadis, bisa ditabung untuk memenuhi keperluannya sendiri kelak diperlukan. Tradisi bertenun banyak dipengaruhi oleh perjalanan waktu dan perubahan zaman. Pada suatu saat ia diperkirakan mengalami kepunahan atau bahkan tetap bertahan dan bangkit kembali. Seiring berjalannya waktu sekarang ini sudah sedikit ditemukan remaja perempuan Silungkang yang mau belajar bertenun. Padahal jika dilihat dari harga songket, penghasilan songket cukup menjanjikan. Serta jika minat remaja perempuan terus menurun hal ini dikhawatirkan dapat mengancam eksistensi songket Silungkang di masa yang akan datang.

Tabel 1 : Data Pengrajin Songket di Kecamatan Silungkang

\begin{tabular}{cccc}
\hline Nama Usaha Tenun & $\begin{array}{c}\text { Jumlah } \\
\text { Karyawan/ Anak } \\
\text { Tenun }\end{array}$ & $\begin{array}{c}\text { Jumlah Remaja } \\
\text { Perempuan yang } \\
\text { Terlibat }\end{array}$ & Alamat/Desa \\
\hline Songket Aina & 100 orang & 2 orang & Silungkang Tigo \\
\hline Songket INJ & 86 orang & - & Silungkang Tigo \\
\hline Songket Misra & 6 orang & - & Silungkang Duo \\
\hline Songket Ibu Fauziah & 50 orang & - & Silungkang Tigo \\
\hline Songket H.j Rahmah & 15 orang & - & Silungkang Tigo \\
\hline Songket Palantai & 15 orang & 4 orang & Silungkang Duo \\
\hline Yurnis Songket & 50 orang & - & Silungkang Duo \\
\hline Songket Siti Bersaudara & 8 orang & - & Silungkang Oso \\
\hline
\end{tabular}

Sumber: Berdasarkan observasi dan wawancara yang dilakukan oleh peneliti

Dari tabel di atas terlihat bahwa hanya 6 orang remaja perempuan yang terlibat dalam usaha tenun di Silungkang. Hal ini menunjukkan kurangnya minat remaja perempuan belajar bertenun pada masyarakat Silungkang. berdasarkan hasil observasi dan wawancara yang dilakukan diketahui bahwa karyawan atau anak tenun usaha songket Silungkang umumnya merupakan tenaga kerja mitralepas, artinya karyawan atau anak tenun bekerja di rumahnya masing-masing dengan diberikan alat produksi serta bahan yang dibutuhkan. Silungkang Tigo dan Silungkang Oso merupakan daerah yang memiliki banyak pengrajin songket mitralepas, sedangkan di Silungkang Duo hanya sedikit pengrajin songket yang ditemukan.

Sehingga berdasarkan fenomena tersebut menarik bagi peneliti untuk meneliti minat remaja perempuan belajar bertenun pada masyarakat Desa Silungkang Duo Kecamatan Silungkang Kota Sawahlunto. Kemudian juga sejauh informasi yang peneliti ketahui, sampai saat ini belum ada penelitian yang secara khusus mengkaji tentang minat remaja perempuan belajar bertenun pada masyarakat Desa Silungkang Duo Kecamatan Silungkang. Berdasarkan uraian tersebut, penulis tertarik melakukan penelitian tentang "Minat Remaja Perempuan Belajar Bertenun Pada Masyarakat Desa Silungkang Duo Kecamatan Silungkang Kota Sawahlunto".

\section{Metode Penelitian}

Penelitian mengenai minat remaja perempuan belajar bertenun pada masyarakat Desa Silungkang Duo Kecamatan Silungkang Kota Sawahlunto dengan pendekatan kualitatif, karena permasalahan dalam penelitian ini bersifat kompleks, dinamis dan penuh makna, sehingga bermaksud untuk memahami situasi sosial secara mendalam (Moleong, 2002). Tipe penelitian yang digunakan adalah studi kasus. Pemilihan informan menggunakan teknik purposive sampling 
yaitu teknik pengumpulan informan yang dilandasi dengan tujuan, maksud, kegunaan, atau pertimbangan, tertentu terlebih dahulu (Sugiyono, 2017). Pemilihan informan dilakukan dengan sengaja berdasarkan kriteria yang sudah ditentukan dan ditetapkan berdasarkan tujuan dari penelitian. Menjelaskan dan mendeskripsikan mengenai penyebab kurangnya minat remaja perempuan belajar bertenun pada masyarakat Desa Silungkang Duo. Adapun yang menjadi informan dalam penelitian ini adalah sebanyak 17 orang yang terdiri dari 7 orang remaja perempuan, 6 orang pemilik usaha tenun, dan 4 orang anggota masyarakat.

Teknik observasi yang diterapkan yaitu partisipasi pasif (passive participation) maksudnya dengan mengamati tempat pemilik usaha tenun dan melihat apakah ada remaja perempuan yang terlibat atau tidak dalam usaha tersebut. Serta juga mengamati kegiatan remaja perempuan yang tidak bertenun. Setelah melakukan observasi peneliti melakukan wawancara dengan informan penelitian. Selain observasi dan wawancara, peneliti juga menggunakan berbagai dokumen dalam menjawab pertanyaan terarah. Studi dokumen merupakan pelengkap dari penggunaan metode observasi dan wawancara dalam penelitian.

Peneliti juga menggunakan teknik triangulasi data agar data penelitian yang diperoleh akurat, valid, dan sah. Triangulasi data merupakan teknik pemeriksaan keabsahan data dengan memanfaatkan sesuatu yang berada di luar data tersebut. Teknik analisis data yang digunakan peneliti yaitu dari Miles dan Huberman melalui analisis yang terdiri dari tiga alur kegiatan, (1) reduksi, (2) penyajian data, dan (3) Kesimpulan/verivikasi.

\section{Hasil dan Pembahasan}

Silungkang merupakan salah satu daerah di Sumatera Barat yang terkenal dengan ciri khas tenun songketnya. Pengrajin songket lebih di didominasi oleh kaum bundo kanduang, terutama remaja perempuan. Namun saat sekarang sudah sedikit remaja perempuan yang ditemukan terlibat dalam usaha tenun Silungkang, terutama di Desa Silungkang Duo. Artinya minat remaja perempuan belajar bertenun saat ini mengalami penurunan. Minat merupakan rasa lebih suka dan rasa ketertarikan pada suatu hal atau kreativitas, tanpa ada yang menyuruh. Minat pada dasarnya adalah penerimaan akan suatu hubungan antara diri sendiri dengan sesuatu di luar diri. Semakin kuat atau dekat hubungan tersebut, semakin besar pula minat yang dimiliki (Slameto, 2010). Jika penurunan minat ini terus dibiarkan dikhawatirkan dapat mengancam eksistensi songket Silungkang di masa yang akan datang. Berdasarkan penelitian yang telah dilakukan, ada beberapa faktor penyebab kurangnya minat remaja perempuan belajar bertenun ini adalah sebagai berikut:

\section{Bertenun Sebagai Suatu Pekerjaan yang Membosankan}

Perasaan jenuh atau bosan merupakan sifat alamiah manusia, hal ini bisa disebabkan oleh beberapa macam faktor antara lain, rutinitas yang monoton terhadap bidang yang digeluti sampai ketidak cocokan terhadap rekan kerja maupun atasan. Monoton artinya dimana dalam bertenun prakteknya dilakukan secara berulang-ulang, serta benang yang kusut akan sulit merapikannya kembali., sehingga menimbulkan rasa bosan. Bertenun dituntut ketelitian untuk menghasilkan kain yang rapi dan bagus. Bertenun dianggap sebagai suatu pekerjaan yang membosankan karena pekerjaannya dilakukan secara monoton, serta dibutuhkan kesabaran dan ketelitian dalam mengerjakannya. Sehingga orang yang mudah jenuh dalam mengerjakan sesuatu akan sulit fokus dalam bidang bertenun ini Serta rasa bosan juga disebabkan oleh pekerjaan yang hanya dilakukan dalam rumah saja dan tidak memiliki teman. Kesendirian akan cenderung menimbulkan kebosanan. Tidak adanya ketertarikan generasi penerus terhadap pertenunan karena proses bertenun dianggap sulit dan butuh waktu lama dalam pengerjaanya, sehingga muncul rasa bosan terhadap bertenun (Anggraini \& Oliver, 2019).

Diharapkan adanya komunitas yang dibentuk untuk meningkatkan motivasi remaja perempuan dalam belajar bertenun. Jika dikaitkan dengan teori motivasi berprestasi McClelland, 
remaja perempuan menginginkan need of affiliation untuk memperoleh hubungan sosial yang baik. Kebutuhan ini ditandai dengan kecenderungan seseorang yang memiliki motif yang tinggi untuk terjalinnya sebuah persahabatan, lebih menyukai situasi kooperatif, dan menginginkan hubunganhubungan yang melibatkan tingkat pengertian mutual yang tinggi. Berdasarkan analisis teori motivasi berprestasi McClelland, dapat diketahui bahwa rendahnya need of achievement yang dimiliki remaja perempuan untuk belajar bertenun. Pandangan rasa bosan terhadap belajar bertenun akibat mereka tidak menguasai indikator latihan yang digunakan untuk belajar bertenun. Sehingga tidak munculnya kreativitas remaja perempuan dalam belajar bertenun tersebut.

\section{Pengaruh Pendidikan}

Pendidikan memiliki pengaruh cukup kuat terhadap alasan berkurangnya minat remaja perempuan dalam bertenun. Salah satu strategi yang tepat dalam membentuk masyarakat yang berkarakter dan bermoral salah satunya melalui pendidikan. Pendidikan mempunyai peran untuk membangun masyarakat yang lebih dewasa (memecahkan konflik/ perbedaan pendapat dengan cara damai, mau belajar mengatur diri sendiri) (Erianjoni, 2015). Saat sekarang remaja perempuan disibukkan dengan aktivitas sekolah, sehingga tidak ada lagi waktu untuk belajar bertenun. Artinya remaja perempuan yang sekolah sulit memiliki waktu untuk bertenun. Karena waktu sudah dihabiskan untuk belajar di sekolah hingga sore hari. Hal ini menyebabkan mereka lelah, sehingga di rumah adalah waktu yang digunakan untuk beristirahat bukan bertenun. Serta pendidikan juga mengubah pola pikir remaja perempuan untuk mendapatkan pekerjaan yang lebih baik, yang mana sarjana dianggap dapat memberikan jaminan pekerjaan. Pendidikan juga dianggap sebagai prestise agar lebih dipandang dalam masyarakat sehingga mendapatkan status sosial yang tinggi. Sehingga beberapa remaja perempuan Desa Silungkang Duo saat ini melanjutkan sekolah hingga ke perguruan tinggi untuk mendapatkan gelar sarjana dengan harapan dapat mendapatkan pekerjaan lebih baik seperti bekerja di instansi pemerintahan. Berdasarkan analisis teori need for achievement McCelland Terlihat dalam kasus bahwasanya minat remaja perempuan belajar bertenun mengalami penurunan, hal ini disebabkan karena ada keinginan merubah nasib dengan menghadapi tantangan yang tidak biasanya, dimana pendidikan dianggap dapat memberikan jaminan pekerjaan yang lebih baik dibandingkan dengan bertenun.

\section{Pilihan Pekerjaan yang Sudah Semakin Banyak}

Saat sekarang kita bisa merencanakan pekerjaan, kita bisa membuat pilihan pekerjaan untuk masa depan. Pekerjaan sesuai dengan minat dan tipe kepribadian adalah adalah idaman setiap orang. Apabila kita bekerja di bidang yang sesuai dengan minat dan tipe kepribadian, umumnya akan jauh lebih sukses dalam menjalani karir, karena pekerjaan terasa lebih menyenangkan. Pilihan pekerjaan saat sekarang sudah semakin banyak, sehingga remaja perempuan sudah bisa memilih pekerjaan yang mereka inginkan sesuai dengan kemampuan yang dimilikinya. Pilihan pekerjaan yang semakin banyak juga merupakan bentuk realisasi dari hasil pendidikan yang semakin maju, dimana remaja perempuan Minangkabau khususnya di Silungkang sekarang sudah bisa bekerja diluar rumah dan ada juga yang merantau (Hendrawati, 2017).

Orang akan cenderung mencari pekerjaan dengan pendapatan yang lebih besar dibandingkan yang kecil. Bertenun sebenarnya memiliki pendapatan yang lumayan apabila ditekuni dan dilakukan dengan teliti. Serta disini juga dituntut kecepatan dan kelincahan dalam mengerjakanSaat sekarang akses untuk memilih pekerjaan lebih banyak dibandingkan dahulu. Dahulu remaja perempuan bertenun karena tidak memiliki pekerjaan lain serta bertenun dilakukan untuk membantu perekonomian keluarga. Sehingga saat sekarang remaja perempuan lebih berminat bekerja di sektor lain dibandingkan dengan bertenun, seperti bekerja pada instansi pemerintahan, berdagang, produksi kerupuk ubi, dan lainnya. Berdasarkan analisis teori motivasi berprestasi McClelland, dapat diketahui bahwa remaja perempuan lebih memilih bekerja di sektor

Culture \& Society: Journal of Anthropological Research Vol. 2, No. 1, Th. 2020 
lain karena target yang akan dicapai dianggap nyata dan memiliki peluang untuk diperoleh serta cenderung menimbulkan kreatifitas pada seseorang.

\section{Kurangnya Motivasi dan Daya Tarik yang Diberikan Kepada Remaja Perempuan Untuk Belajar Bertenun}

Motivasi merupakan konstruk hipotesis yang digunakan untuk menjelaskan keinginan, arah, intensitas, dan keajegan perilaku yang diarahkan oleh tujuan. Dalam motivasi terdapat beberapa konsep seperti kebutuhan untuk berprestasi, kebutuhan berafiliasi, kebiasaan, dan keinginan seseorang terhadap sesuatu. Kurangnya motivasi dan daya tarik yang diberikan kepada remaja perempuan untuk belajar bertenun, yang mana masyarakat dan pemerintah setempat kurang memberikan motivasi agar remaja perempuan minat belajar bertenun (Ridho, 2020). Kesempatan melatih remaja perempuan khususnya yang putus sekolah merupakan sesuatu yang tidak mudah karena generasi muda sekarang telah dihinggapi satu keadaan yang apatis/ sikap cuek terhadap lingkungan. Hal ini juga dipengaruhi oleh dampak negatif perkembangan jaringan internet yang bebas lepas kontrol oleh orang tua serta juga dipengaruhi oleh budaya asing yang mudah ditiru layaknya pergaulan bebas dan penggunaan zat aditif lainnya (Zulkarnaen \& Latief, 2017).

Pelestarian budaya harus dikembangkan melalui kebijakan pemerintah sehingga membuat para pengrajin tenun kembali bergairah untuk menekuninya karena memiliki nilai ekonomis. Pewarisan keterampilan bertenun tidak hanya terbatas pada keluarga pengrajin melainkan juga sudah melus kepada masyarakat yang meminatinya. Pemerintah diharapkan mendukung dengan berbagai program dan kebijakan agar keterampilan bertenun tetap bertahan dan berkembang di tengah masyarakat Desa Silungkang Duo Kecamatan Silungkang Kota Sawahlunto, terutama yaitu remaja perempuan (Hasbullah, Wilaela, 2020). Untuk meningkatkan proses regenerasi produksi tenun kepada remaja perempuan juga perlu diupayakan kerjasama baik swasta maupun pemerintah (dinas pendidikan). Sebagai saran terkait dengan proses regenerasi, perlu diusulkan ke dinas pendidikan propinsi Sumatera Barat atau Kota Sawahlunto agar kegiatan bertenun bagi anak-anak usia sekolah dijadikan sebagai kegiatan formal (wajib) ekstrakurikuler di tingkat SD, SMP, maupun SMA (Suharsono, 2018). Pemerintah daerah juga bisa meningkatkan minat remaja perempuan belajar bertenun dengan mengikutsertakan pengrajin songket khususnya remaja perempuan ke dalam kegiatan pameran secara rutin setiap tahunnya, baik di dalam provinsi, antar provinsi maupun luar negeri (Budiana, 2014).

Untuk menganalisis minat remaja perempuan belajar bertenun motivasi berprestasi yang dikembangkan oleh McClelland. Menurut McClelland, setiap individu memiliki kebutuhan sendiri-sendiri sesuai dengan karakter serta pola pikir yang membentuknya. McClelland menjelaskan bahwa setiap individu memiliki dorongan yang kuat untuk berhasil. Dorongan ini mengarahkan individu untuk berjuang lebih keras untuk memperoleh pencapaian pribadi ketimbang memperoleh penghargaan (Susanto and Lestari, n.d.). Keinginan untuk meraih prestasi itu mutlak dimiliki oleh setiap orang, berbagai macam cara ditempuh seseorang untuk menggapainya. Semakin tinggi prestasi yang diinginkan maka semakin keras pula usaha yang harus dikeluarkan. McClelland menjelaskan bahwa untuk berhasil setiap individu harus memiliki dorongan yang kuat. Dorongan ini mengarahkan individu untuk berjuang lebih keras untuk memperoleh pencapaian pribadi daripada memperoleh penghargaan. Terlihat dalam kasus bahwasanya minat remaja perempuan belajar bertenun mengalami penurunan, hal ini menandakan rendahnya $n A c h$ yang dimiliki remaja perempuan untuk belajar bertenun. Oleh karena itu dibutuhkan peran pemerintah dan masyarakat untuk meningkatkan need for achievement remaja perempuan untuk belajar bertenun. Sehingga dapat meningkatkan minat remaja perempuan belajar bertenun pada masyarakat Desa Silungkang Duo Kota Sawahlunto. 


\section{Kesimpulan}

Berdasarkan hasil penelitian yang peneliti lakukan dilapangan dapat disimpulkan bahwa minat remaja perempuan belajar bertenun pada masyarakat desa Silungkang Duo Kecamatan Silungkang Kota Sawahlunto saat sekarang mengalami penurunan. Berkurangnya minat remaja perempuan dalam belajar bertenun disebabkan oleh empat faktor yaitu, dianggap sebagai suatu pekerjaan yang membosankan, pengaruh pendidikan, pilihan pekerjaan yang sudah semakin banyak, dan kurangnya motivasi dan daya tarik yang diberikan kepada remaja perempuan untuk belajar bertenun. Bertenun dianggap sebagai suatu pekerjaan yang membosankan karena pekerjaannya dilakukan secara monoton, serta dibutuhkan kesabaran dan ketelitian dalam mengerjakannya. Faktor lain yang menyebabkan kurangnya minat remaja perempuan belajar bertenun adalah pengaruh pendidikan, yang mana saat sekarang remaja perempuan disibukkan dengan aktivitas sekolah, sehingga tidak ada lagi waktu untuk belajar bertenun. Serta pendidikan juga mengubah pola pikir remaja perempuan untuk mendapatkan pekerjaan yang leb ih baik, yang mana sarjana dianggap dapat memberikan jaminan pekerjaan. Faktor lain yang menyebabkan kurangnya minat remaja perempuan belajar bertenun adalah pilihan pekerjaan yang sudah semakin banyak, sehingga remaja perempuan bisa bebas memilih pekerjaan yang mereka inginkan sesuai dengan kemampuan yang dimiliki. Faktor lain yang menyebabkan kurangnya minat remaja perempuan belajar bertenun adalah kurangnya motivasi dan daya tarik yang diberikan kepada remaja perempuan untuk belajar bertenun, yang mana masyarakat dan pemerintah setempat kurang memberikan motivasi agar remaja perempuan minat belajar bertenun, sehingga kurangnya motivasi dan daya tarik yang diberikan menyebabkan kurangnya minat remaja perempuan belajar bertenun. Faktor-faktor ini menyebabkan kurangnya minat remaja perempuan dalam belajar bertenun.

\section{Daftar Pustaka}

Aminah, Hos, J., \& Sarpin, S. (2020). Peran Wanita dalam Melestarikan Kerajinan kain Tenun Buton di Desa Wabula Kecamatan Wabula Kabupaten Buton. Jurnal Pemikiran dan Penelitian Sosiologi, 7(1), 2355-1445.

Anggraini, A. R., \& Oliver, J. (2019). Metode dan Pola Pewarisan Pengetahuan dan Keterampilan Menenun Kain Sutera Pada Perempuan Pengrajin Kain Sutera di Kabupaten Wajo. Laporan Penelitian. Universitas Negeri Makassar.

Budiana, R. N. S. (2014). Strategi Pengembangan Tenun Ikat Kupang Provinsi Nusa Tenggara Timur. Jurnal Pendidikan dan Kebudayaan, 20(3), 1-15.

Erianjoni, E. (2015). Integrasi Nilai-nilai Kearifan Lokal Minangkabau ke dalam Materi Ajar Sosiologi dalam Pembentukan Karakter Peserta Didik. Jurnal Tingkap, 11(1), 1-21.

Hasbullah, H., \& Wilaela, R. S. (2020). Menenun bagi Perempuan Melayu Riau: Antara Peluang Usaha dan Pelestarian Budaya. Jurnal Studi Gender, 13(1), 1-15.

Hendrawati, H. (2017). Wanita Perajin Tenun Tradisional di Nagari Halaban, Kecamatan Lareh Sago Halaban Kabupaten Lima Puluh Kota, Sumatera Barat. Jurnal Antropologi, 18(2), 119.

Maulia, R. (2015). Wisata Budaya dalam Tradisi Tenun di Kecamatan Mempura Kabupaten Siak. Jurnal Fisip, 2(2), 1-11.

Moleong, L. (2002). Metode Penelitian Kualitatif. Bandung: Rosdakarya.

Ridho, M. (2020). Teori Motivasi Mc Clelland dan Implikasinya dalam Pembelajaran PAI. Jurnal Studi Kesilaman dan Ilmu Pendidikan, 8(2), 1-16.

Slameto, S. (2010). Belajar dan Faktor-faktor yang Mempengaruhinya. Jakarta: Bina Aksara

Sugiyono, S. (2017). Metode Penelitian Kuantitatif, Kualitatif, dan R\&D. Jakarta: Alfabeta. 
Resti Yulia Putri, Erianjoni Erianjoni Minat Remaja Perempuan Belajar Bertenun Pada Masyarakat Desa Silungkang Duo Kecamatan Silngkang Kota Sawahlunto

Suharsono, S. (2018). Pemberdayaan Wirausahawan Sosial dalam Pengembangan Kewirausahaan. Jurnal Prosiding PKM-CSR, 1(1), 1-10.

Sumiati, Y. (2019). Kerajinan Songket Jambi (Studi Kasus di Sentra Susi Songket Kel. Handil Jaya Kec. Jelatung Kota Jambi). Jurnal Kapita Selekta Geografi, 2(1), 138-148.

Susanto, S. \& Lestari, L. (2018). Problematika Pendidikan Islam di Indonesia. Edukasia Islamika, 3(2), 184-202.

Zulkarnaen M., \& Latief, A. Z. (2017). Pelatihan Tenun dari Limbah Lidi Kelapa Sawit dengan Menggunakan ATBM bagi Remaja di Kabupaten Aceh Tamiang. Jurnal Pengabdian Kepada Masyarakat, 23(4), 1-8. 